\title{
EDITORIAL.
}

A revista Contracampo, uma publicação do Programa de Pósgraduação em Comunicação (PPGCOM) da Universidade Federal Fluminense, está classificada no sistema Qualis da CAPES como Nacional A. Tal avaliação refere-se não somente à circulação da revista em todo o país, mas também à observação atenta dos trabalhos produzidos pelos pesquisadores de comunicação das mais variadas regiões do Brasil.

Neste número, confirmamos o compromisso acima através da publicação de 14 artigos provenientes de sete estados da União, representados por oito diferentes universidades. E queremos ressaltar que a seleção foi baseada em severos critérios de qualidade acadêmico-científica, o que demonstra que a produção na área mantém um mesmo nivel de excelência independentemente da procedência. Em um país de dimensões continentais, tal conclusão nos parece motivo para uma valorização ainda maior das pesquisas em comunicação por parte dos órgãos de fomento e das agências reguladoras.

Mesmo mantendo nossa fundamental caracteristica de apresentar um dossiê temático ao leitor, foi possivel apresentar uma visão diversificada e abrangente sobre o tema que escolhemos: Comunicação e Imagem. A divisão em sub-temas (cinema, televisão e fotografia) foi determinada pela própria dinâmica dos textos enviados, que certamente foram influenciados pela ênfase expressa pelo editor-chefe durante o Call For Papers. Cabe lembrar, entretanto, que a escolha do assunto segue as linhas de pesquisa de nossos programas de mestrado e doutorado. Desta forma, como no número anterior apresentamos artigos relacionados à mediação e à tecnologia, nesta edição optamos pela imagem, que é nossa terceira área de estudos. 
Para finalizar, desejo a todos uma boa leitura e me coloco à disposição para quaisquer esclarecimentos sobre nossa publicação. $\mathrm{Na}$ citação de Maiakovski, "sei o pulso das palavras. Não as que se aplaudem do alto dos teatros, mas as que arrancam os caixões da treva e põem os poemas a caminhar".

\section{Felipe Pena'}

'Editor-chefe da Contracampo. Jornalista. Doutor em Literatura. Professor do PPGCOM em Comunicação da UFF. Professor visitante da Universidade de Salamanca, na Espanha. Autor de sete livros na área de comunicação, entre eles "Teoria do Jornalismo" (S.P., Ed. Contexto, 2005) e "Televisão e Sociedade" (R.J., Ed. Sette Letras, 2002). Página na web: www.felipepena.com / E-mail: felipepena@globo.com 